\title{
Human Perceptions of Megafaunal Extinction Events Revealed by Linguistic Analysis of Indigenous Oral Traditions
}

\author{
Priscilla M. Wehi ${ }^{1,2}$ (D) Murray P. Cox ${ }^{3} \cdot$ Tom Roa $^{4} \cdot$ Hēmi Whaanga ${ }^{4}$
}

Published online: 4 June 2018

(C) The Author(s) 2018

\begin{abstract}
Human settlement into new regions is typically accompanied by waves of animal extinctions, yet we have limited understanding of how human communities perceived and responded to such ecological crises. The first megafaunal extinctions in New Zealand began just 700 years ago, in contrast to the deep time of continental extinctions. Consequently, indigenous Māori oral tradition includes ancestral sayings that explicitly refer to extinct species. Our linguistic analysis of these sayings shows a strong bias towards critical food species such as moa, and emphasizes that Māori closely observed the fauna and environment. Temporal changes in form and content demonstrate that Māori recognized the loss of important animal resources, and that this loss reverberated culturally centuries later. The data provide evidence that extinction of keystone fauna was important for shaping ecological and social thought in Māori society, and suggest a similar role in other early societies that lived through megafaunal extinction events.
\end{abstract}

Keywords Cultural evolution · Indigenous resource management · Megafauna · Moa · Oceania · New Zealand · Maori · Socio-ecological systems · Traditional ecological knowledge

Electronic supplementary material The online version of this article (https://doi.org/10.1007/s10745-018-0004-0) contains supplementary material, which is available to authorized users.

Priscilla M. Wehi

wehip@landcareresearch.co.nz

Murray P. Cox

M.P.Cox@massey.ac.nz

Tom Roa

tomroa@waikato.ac.nz

Hēmi Whaanga

hemi@waikato.ac.nz

1 Centre for Sustainability, University of Otago, PO Box 56, Dunedin 9054, New Zealand

2 Te Pūnaha Matatini, Manaaki Whenua - Landcare Research, 764 Cumberland St, Private Bag 1930, Dunedin 9054, New Zealand

3 Te Pūnaha Matatini, Statistics and Bioinformatics Group, Institute of Fundamental Sciences, Massey University, Private Bag 11 222, Palmerston North 4442, New Zealand

4 Faculty of Māori and Indigenous Studies, University of Waikato, Private Bag 3105, Hamilton 3240, New Zealand

\section{Introduction}

Island ecosystems act as natural laboratories for understanding the processes of extinction (Carlquist 1974; Prebble and Wilmshurst 2009), including the role of, and impact upon, human communities. The Pacific Ocean was one of the last regions settled by humans, and its extinction timeline is therefore more recent than on the continents. However, even in the Pacific, most major extinction phases occurred well before written records. Consequently, although we know a great deal about the science of extinction events from archaeological and other data, we still understand little about how human communities perceived, and responded to, the resulting ecological crises, or the development of community conservation 'rules' and actions by these communities. By applying a combination of quantitative and qualitative linguistic methods, we have explored indigenous responses to major faunal extinctions in one commonly used form of oral tradition, whakatauki. In New Zealand, settled as recently as AD 1280 (Wilmshurst et al. 2008; Perry et al. 2014), the strong oral tradition among indigenous Māori includes a series of ancestral sayings (whakatauki) that provide glimpses into the island's early extinction events and their importance as cultural signposts. In generalized form, our findings may shed light on how other 
societies became aware of, and responded to, earlier animal extinctions across Eurasia and the Americas.

In common with other Pacific island environments, the arrival of humans in New Zealand resulted in high rates of extinction among its predominantly avian fauna (Duncan et al. 2002; Bromham et al. 2012). The species most affected were those especially vulnerable to human hunters, including the group of large, flightless birds known as moa [Aves: Dinornithiformes] (Holdaway 1989; Worthy 1997; Cassey 2001). Detailed reconstruction of Holocene bird fauna indicates that approximately 28 land bird species became extinct on the two main islands of New Zealand in the 500 years between initial settlement by Māori (c. AD 1280) and first European contact (AD 1769) (Worthy and Holdaway 2002; Tennyson 2006; Wood 2013). Berkes (2008) argues that ecological crises trigger learning in human communities, which in turn shapes subsequent resource management practices. However, few studies have explored the development of conservation learning in response to ecological crises, and despite the rapid loss of major avian megafauna in New Zealand less than 700 years ago (Holdaway and Jacomb 2000; Tennyson 2006; Allentoft et al. 2014; Perry et al. 2014) how this ecological change affected cultural learning remains essentially unknown.

Quantitative analysis of linguistic markers to determine the timing and evolution of manuscripts has been increasingly employed over the last 20 years (Barbrook et al. 1998; Spencer et al. 2004; Eagleton and Spencer 2006; Howe and Windram 2011). More recently, these analyses have been extended to investigate the cultural legacies of folk tale records, some of which likely originated before the emergence of written records (da Silva and Tehrani 2016). The contexts in which communications take place also shape linguistic form and length (Wray and Grace 2007). Linguistic theory suggests that communication within close family groupings is dominated by implicit meaning. This contrasts with the cues that dominate exoteric language used by distantly related groups, such as increased length and transparency (Wray and Grace 2007). Ecological information conveyed in ancestral sayings during early human settlement phases in a new land is thus likely embedded implicitly in short phrases. Here, we use linguistic, historical and structural cues in a body of whakatauki to analyze the development of socioecological thought over a period of c.650 years from the time of Polynesian arrival in New Zealand.

We first hypothesised that large bodied animals, such as the flightless moa, would predominate in Māori whakataukī if food sources were an important preoccupation for these settlers. Avian body size is a significant predictor of hunting intensity across the Pacific (Duncan et al. 2002), and moa a group of ratites that ranged from the size of a turkey to much larger than an ostrich - were a primary food and tool resource for the Polynesian ancestors of the indigenous Māori people of New Zealand (Anderson 1989), given the lack of native mammals in New Zealand. Second, we predicted that the form and content of whakataukī over time would reflect rapid and ongoing socioenvironmental evolution associated with new settlement (Wray and Grace 2007). We expected that whakataukī length would reflect social change. Specifically, we hypothesized that early settlement in close-knit family groupings, where relevance and implied contexts were wellunderstood within the group would result in shorter whakatauki whereas in the changing environments of rapid settlement expansion and the formation of larger sub-tribal and tribal groupings, alliances, and warfare the context of whakatauki would be less well understood and they would, on average, increase in length (Wray and Grace 2007). Finally, we predicted that major negative environmental change, such as the loss of critical megafaunal food species, should drive a progression from immediate observations of loss to a generalized understanding of the causes of extinction and finally to the deployment of explicit ecological management practices in keeping with the development of conservation practice (Best 1904; Berkes 2008; Bowman et al. 2015).

\section{Materials and Methods}

Prior to European arrival in the late seventeenth century, Māori was a pre-literate language with a strongly developed oral tradition and a large unwritten literature of songs, poetry, and proverbs as in many indigenous cultures. This tradition uses whakataukī, as well as narratives (pūrākau) that contain philosophical thought, metaphor (kupu whakarite), epistemological constructs, cultural codes, worldviews, and song (waiata) in everyday life. Whakatauki formed an important part of this tradition (Mead and Grove 2001; Wehi 2009). It is important to note that although the translation of whakatauki as 'ancestral sayings' suggests an association with historic oral tradition, these sayings are still widely used by orators and speakers of Māori today.

\section{Dataset}

European settlement in NZ was initiated shortly after 1800, and gathered momentum in the second half of the nineteenth century (Fig. 2). During this period, many early European ethnographers recorded and compiled Māori oral tradition, including Grey, Colenso, Smith, White, Williams, Best, and Firth (Supplementary Materials). These source materials, along with other archived records, were comprehensively compiled, revised, translated, and interpreted by Mead and Grove (2001) with the later addition of translations and interpretations. We used this pariemological dataset of 2669 whakatauki as our primary dataset, supplemented by similar entries from other compilations (total $n=3421$; see electronic supplementary materials for details). From this dataset, we analysed 657 whakatauki that explicitly refer to fauna. 


\section{Time Attribution}

Drawing from Mead's (1984) classification of the temporal development of Māori artistry, and Davidson's (1984) cultural phases, each faunal whakatauki was assigned to one of five broad time periods: before AD 1350 (pre-dating Māori settlement of New Zealand), 1350-1500 (the very early New Zealand settlement period), 1500-1650 (rapid settlement expansion), 16501800 (intertribal fighting and early European contact) and post1800 (the period following European contact). These time periods equate approximately, in English literature terms, to the early Anglo-Saxon period of Beowulf ( 1000 AD); to that of Chaucer ( 1343-1400); Shakespeare (1564-1616); Jonathan Swift (1667-1745); and Charles Dickens (1812-1870). To assign faunal whakataukī to these temporal categories, we called upon TR, a Māori linguist, translator, historian, and native speaker, to derive estimated chronological dates for the whakatauki without any prior knowledge of the hypotheses of the study (see below for validation) so that we could establish relationships both between different versions of the same whakatauki, and between whakatauki with different content (Table 1).

TR used linguistic and structural cues, vocabulary identifications, historical contexts and embedded references to ancestor names, events, and genealogies to make these temporal assignments (Roa 2016) (Table 1). For example, specific historical details form the context for the whakatauki on fish shown in Table 1. In other whakataukī, estimated dates of species arrivals (e.g., for pītongatonga, after European arrival) and old and modern word usages and transliterations (e.g., pi and heihei) were used to cross reference dating.

\section{Validation of Time Period Assignments}

Scoping tests demonstrate that expert linguistic training is necessary for accurate dating over and above native-speaker and community elder status (Chipere 2000). As a result, we devised a blind validation test to confirm the ability of our language expert and co-author (TR) that used Māori sentences with no temporal context taken from two time periods (late nineteenth century, early twenty-first century) to obtain a reliability value for distinguishing early and late sentence structures dating from approximately a century apart. We presented TR with a randomized set of sentences of comparable length (approximately $15-50$ words) from oral recordings in the Māori language, with 100 examples selected from each of two time periods (Table S4).

Sentences were selected from six speakers of Māori who were recorded in the 1940s, but were born around the 1870s. These are regarded as the landmark early Māori oral recordings and have been used extensively in other comparative studies (Keegan et al. 2014). These were compared with sentences taken from 58 Māori speakers who were recorded on Te Karere (a news and current affairs television program broadcast on state television in Māori) that aired in late November/ December 2015. The program's content focuses on topics of national significance to the targeted Māori audience.

The mobile unit of the National Broadcasting Service made recordings of Māori speakers between 1946 and 1948. The Unit made three tours: two in the North Island, covering the West Coast from Wanganui to Waitara in late 1946, and the Waikato and Thames Valley districts in 1947, and one in the South Island to the Otago region in 1948. Sentences were selected in the following way. First, for the speakers born in the 1870s, we demarcated each new topic of conversation, and selected the first sentence after the third sentence that was between 15 and 50 words in length. Each sentence was checked for any obvious words or dates that would provide the informant with explicit temporal information (e.g., references to World War II). If the first example was deemed unsuitable, or if parts were inaudible, the next example of 15-50 words was selected and checked for suitability. For the second set of speakers, we excluded sentences spoken by the interviewer as these are normally scripted rather than representing impromptu speech. We then selected the first sentence of the interviewee of between 15 and 50 words in length. A maximum of five sentences was selected from a single speaker (Table S4).

Language expert TR achieved a hit rate of $81 \%$ and error rate of $19 \%$, yielding a sensitivity index $d$ ' of 1.76 . Sentences from the early period were assigned with slightly more accuracy (86\%) than sentences from the late period $(76 \%)$. The null hypothesis that the language expert assigns sentences randomly to the early and late periods can therefore be rejected both for the set of early sentences $\left(\chi_{1}^{2}=13.4, P=0.00025\right)$ and the set of late sentences $\left(\chi_{1}^{2}=28.2, P=0.00000011\right)$. Given this discriminatory power for two time periods separated by only 100 years, the whakatauki were likely assigned to five much wider time periods with similar or better accuracy.

\section{Knowledge Development}

We classified whakataukī according to Berkes' (2008) mechanisms of knowledge development (i.e., observation and monitoring, trial and error experimentation, learning from other places and times, and knowledge encoded in language and other narratives) to examine key developments in traditional knowledge, practice, and resource management over these time periods. In addition, we examined whakatauki using a model proposed by Crombie (1985a, b, 1987) and Whaanga (2006) that identifies mechanisms of human thinking and language structure based on cognitive processes. The model uses four main distinctions (temporal, additive, associative, and causal) to explore connections between the development of knowledge through time and language structure shifts and time periods. To make these classifications, the model identifies discourse relations, and the presence and absence of 
Table 1 Examples showing how linguistic cues, historical and cultural context, and identification of events and ancestor names inform chronological dating of whakatauki

\begin{tabular}{|c|c|c|c|c|}
\hline Example & Theme & English translation & Time period & Explanation \\
\hline \multicolumn{5}{|l|}{ (a) Moa } \\
\hline 1. Mate ā-moa & Extinction & Dead as the moa & $1500-1650$ & \multirow{10}{*}{ 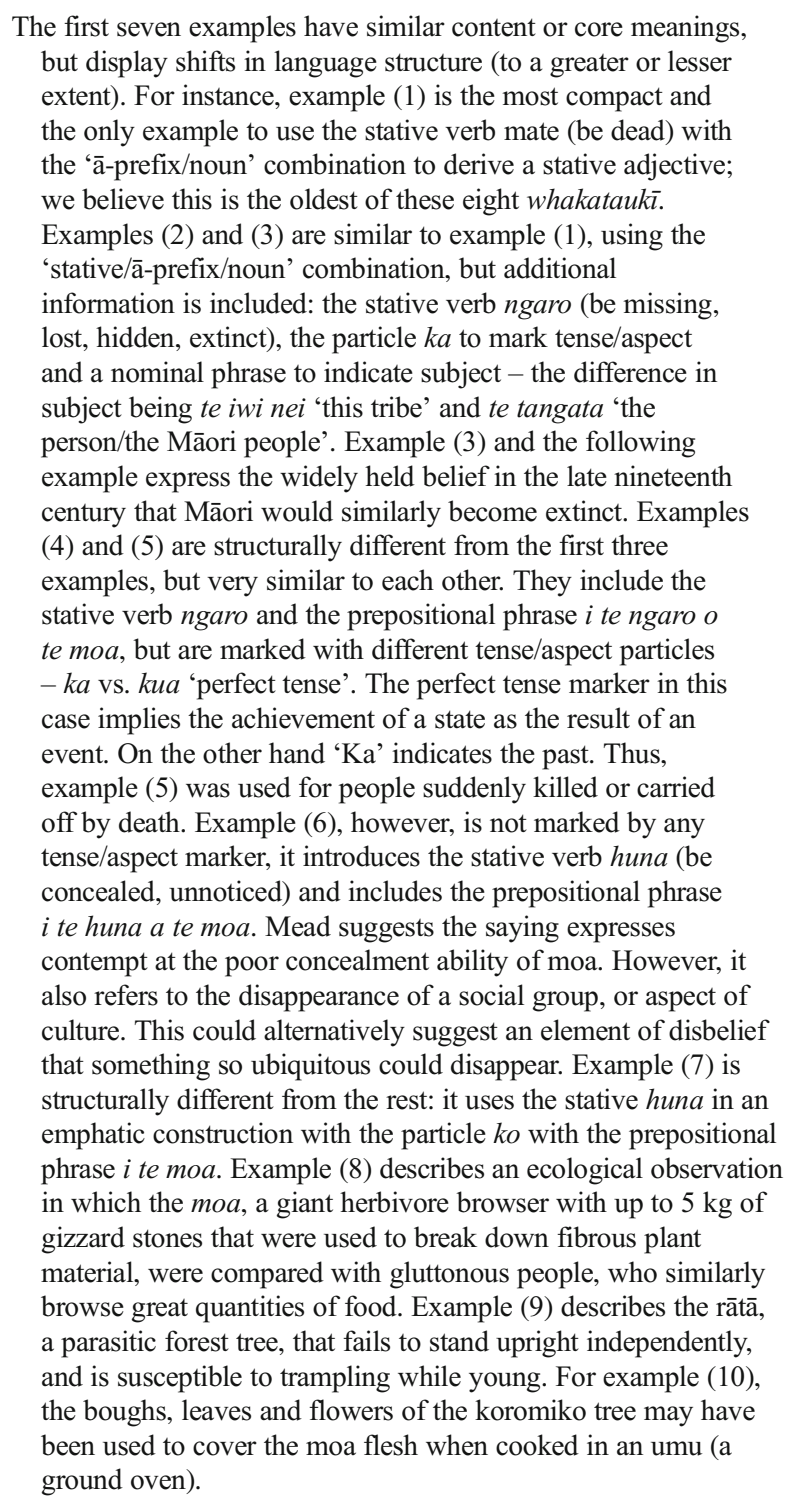 } \\
\hline $\begin{array}{l}\text { 2. Ka ngaro ā-moa } \\
\text { te iwi nei }\end{array}$ & Extinction & $\begin{array}{l}\text { This tribe will disappear } \\
\text { like the moa }\end{array}$ & $1800-$ & \\
\hline $\begin{array}{l}\text { 3. Ka ngaro } \bar{a}-\mathrm{moa} \\
\text { te tangata }\end{array}$ & Extinction & $\begin{array}{l}\text { The Māori will become } \\
\text { extinct like the moa }\end{array}$ & $1800-$ & \\
\hline $\begin{array}{l}\text { 4. Ka ngaro i te } \\
\text { ngaro o te moa }\end{array}$ & Extinction & $\begin{array}{l}\text { Lost like the loss of the } \\
\text { moa }\end{array}$ & $1800-$ & \\
\hline $\begin{array}{l}\text { 5. Kua ngaro i te } \\
\text { ngaro o te moa }\end{array}$ & Extinction & $\begin{array}{l}\text { Perished as the moa } \\
\text { perished }\end{array}$ & $1500-1650$ & \\
\hline $\begin{array}{l}\text { 6. Huna i te huna } \\
\text { a te moa }\end{array}$ & Extinction & Hidden as the moa hid & $1800-$ & \\
\hline $\begin{array}{l}\text { 7. Ko te huna } \\
\text { i te moa! }\end{array}$ & Extinction & $\begin{array}{l}\text { It is like the disappearance } \\
\text { of the moa }\end{array}$ & $1650-1800$ & \\
\hline 8. He puku moa! & $\begin{array}{l}\text { Ecological } \\
\text { observation }\end{array}$ & A stomach of a moa! & $1350-1500$ & \\
\hline $\begin{array}{l}\text { 9. He rātā te rākau } \\
\text { i takahia e te moa }\end{array}$ & $\begin{array}{l}\text { Ecological } \\
\text { observation }\end{array}$ & $\begin{array}{l}\text { A rātā was the tree } \\
\text { trampled by the moa }\end{array}$ & $1500-1650$ & \\
\hline $\begin{array}{l}\text { 10. He koromiko te } \\
\text { wahie i taona ai } \\
\text { te moa }\end{array}$ & $\begin{array}{l}\text { Food } \\
\text { preparation }\end{array}$ & $\begin{array}{l}\text { Koromiko is the wood } \\
\text { with which the moa } \\
\text { was cooked }\end{array}$ & $1500-1650$ & \\
\hline
\end{tabular}

(b) Fish

Hā! He ika poto Historical te ika nei!

(c) Chicken
Ai pī
Breeding
Chicken breeding. What! A short fish,
this one'
1500-1650 Specific historical details form the context for this saying, and can thus be used to help identify its chronology. Awakanoi of Ngāti Awa was slain by near Rūâtoki. According to Best (1925), when the body was turned over to reveal its identity, the victor uttered this saying. It apparently meant he had hoped for a more prominent victim. Another explanation is that Ipuhue was disappointed that the victim had not provided more of a contest.

before 1350 Referring to a prolific parent with numerous children, this whakataukī has been identified as pre-dating Māori settlement. Overpopulation is a recurring rationale for Māori departure from Hawaiki in oral tradition. Domestic chickens either were not carried, or did not survive on canoes during the journey to Aotearoa New Zealand. 
relational signaling and encoding (i.e., coherence, cohesive devices, co-ordination, subordination, conjuncts, and lexis) with linguistic and world knowledge (i.e., prior understandings) (Roa 2016; Supplementary Materials). Using these classification techniques, we were able to establish relationships between different versions of the same whakatauki, and whakatauki with different content.

\section{Word Frequencies}

Qualitative analyses included inspection of word frequencies in whakatauki. All function words (such as 'a,' 'the,' and 'in') were removed from the dataset using standard UNIX operations (particularly the command line program 'grep'). Word frequencies were determined using an online word counting tool (http://www.textfixer.com/tools/online-word-counter. php; accessed April 2017).

\section{Bird Data}

We used Dunning (2007) to determine mean weights for all bird species (Table S1, Supplementary Materials), and then regressed these weights against total word occurrence for that species or group in the whakatauki faunal dataset. Prevalence of bird species across New Zealand archaeological sites (Fig. 2) was obtained from Worthy (1999).

\section{Use of Māori and English Bird Names}

We have used bird and plant names that are common usage in New Zealand to refer to species reported in this paper. In some cases these are Māori (e.g., kiwi, miro), and in some cases English (e.g., blue duck). We have not italicized these names, but provide the appropriate scientific name on first usage to assist the reader with identification. In addition, all scientific names for birds represented in Fig. 1 along with their average weights, and all scientific names for birds that became extinct on the two main islands of New Zealand, have been provided in Tables S1 and S2.

We note that Māori names do not always map cleanly to modern taxonomic units. Bird names in Fig. 2 may therefore refer to closely related and morphologically similar species, such as moa, albatross, shag, kiwi, and kākāriki (native parakeets). Morphologically similar birds from the same genus that are now described as different species on the North and South Islands are often described by a single common name, such as 'snipe,' 'saddleback,' and 'kōkako.' In Fig. 2, some bird names have also been shortened for visual clarity: 'bittern' refers to the New Zealand bittern, 'godwit' to the bartailed godwit, 'oystercatcher' to the variable oystercatcher, 'heron' to the white heron, and 'quail' to the extinct New Zealand quail. Macrons are not shown for names on the plot.

\section{Historical Reports of Moa}

We considered whether the whakatauki referring to moa and their extinction that were identified as dating to the nineteenth century were in part a product of the intense scientific interest that arose near that time about this bird. Anderson (1989) has inferred that the controversy generated within the scientific community about the discovery of moa, and its apex predator the Haast's Eagle, likely preceded or stimulated the recording of sayings about moa during the post European period, and suggests that the moa were as common a symbol in public imagery then as the kiwi is today. However, a closer evaluation of the evidence suggests otherwise (Supplementary Materials). Governor George Grey asserted that Māori all knew the word moa as 'a bird well known to their ancestors.' Grey also recorded the lament of Ikaherengutu that includes references to moa, and was sung by Te Wherowhero on the death of his brother (see Supplementary Materials for further details). Because Anderson's survey of oral tradition was
Fig. 1 Relative frequency of words in the faunal subset of Māori whakataukī, translated here into English. Function words have been removed

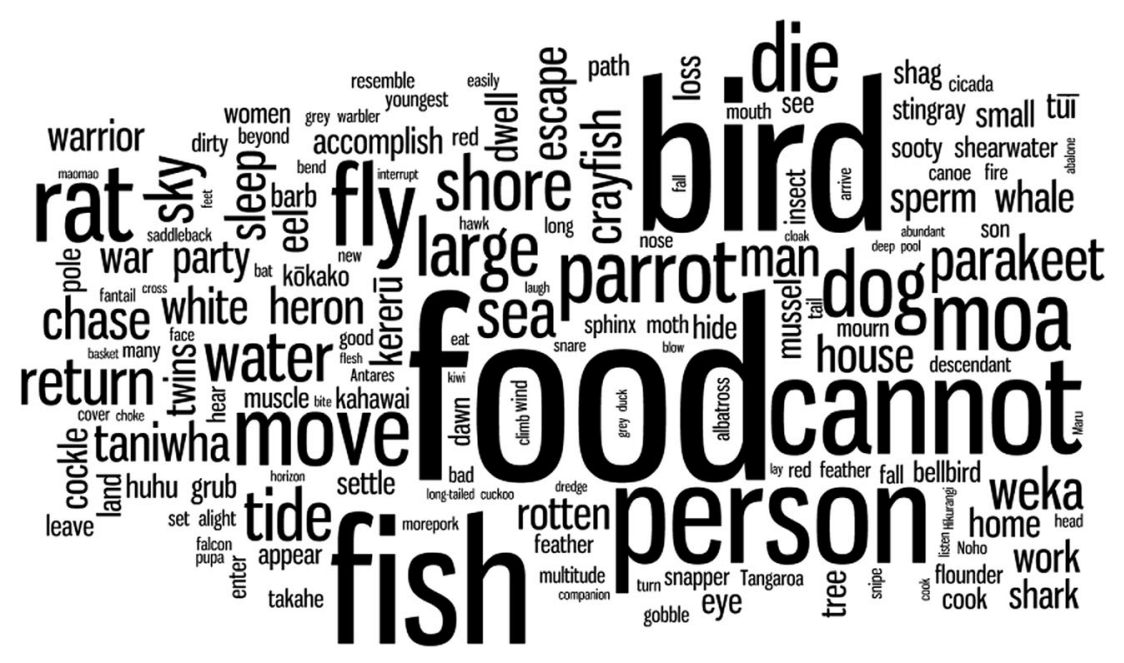


Fig. 2 Large birds (pictures scaled according to size; Table S1) are discussed more often than small birds in whakatauki and are found at a larger number of archaeological sites. Moa are heavily represented in whakatauki; a moa head only is shown due to their disproportionately large size. Birds represented in blue (i.e.moa and pouakai) became extinct prior to European arrival - but other extinct birds do not occur in the whakatauki and are thus not shown in the figure (Table S2). Data from archaeological sites are from Worthy (1999), shown with permission

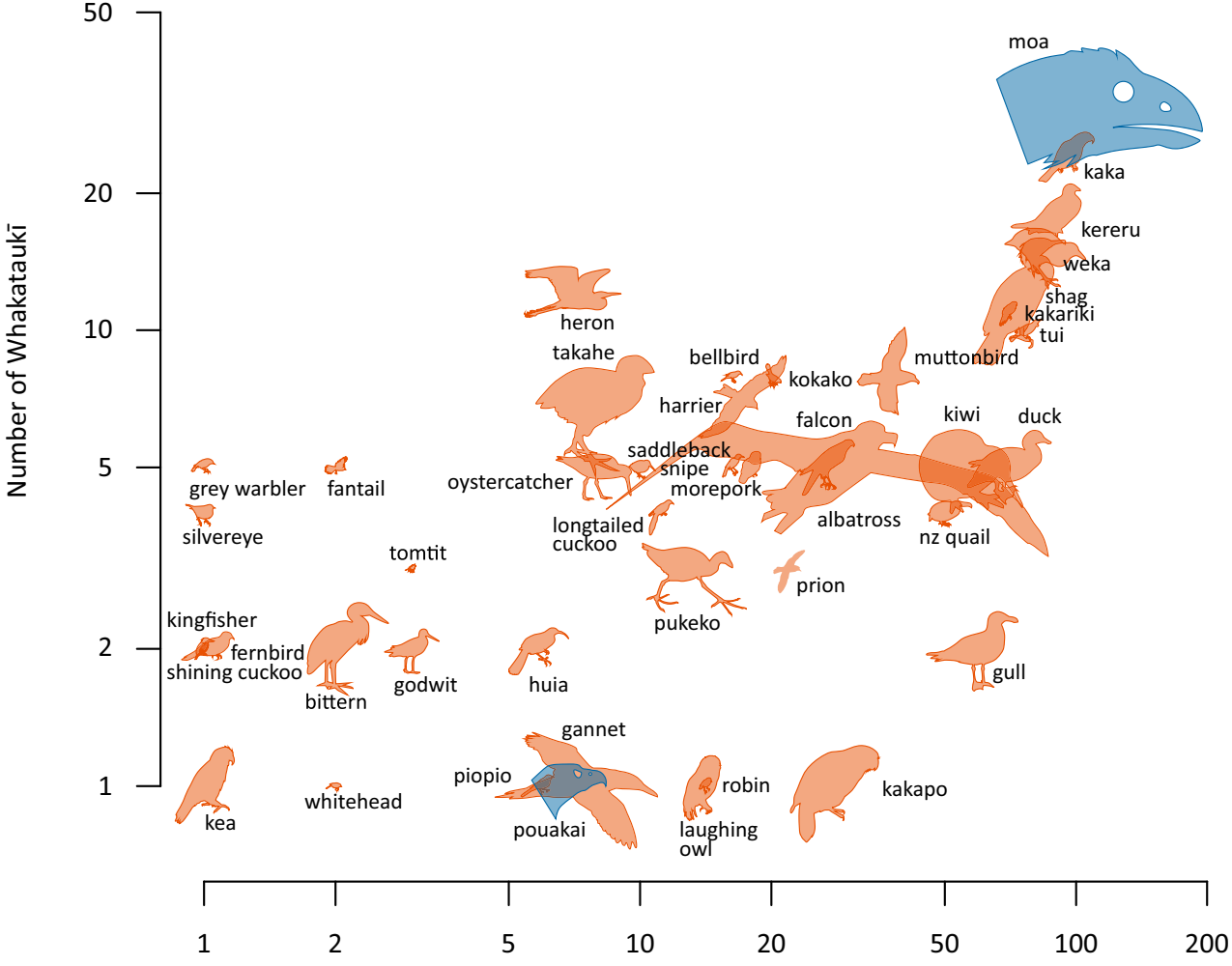

Number of Archaeological Sites primarily limited to narratives (pūrākau) a number of critical references to moa in waiata (song) and whakatauki were not identified.

\section{Statistical Analyses}

All statistical approaches were implemented in $\mathrm{R}(\mathrm{R}$ Development Core Team 2010).

\section{Results}

Among the faunal set of whakatauki, the most frequent word is 'food' (kai), indicating that subsistence was indeed a high priority (Fig. 1). As predicted, large birds are more frequently mentioned in whakatauki than small birds ( $n=657$ whakatauk $; r=0.60, P$ $<0.0001$, Fig. 2), consistent with the same trend whereby large birds are more commonly found in archaeological sites than small birds ( $n=112$ sites; $r=0.41, P=0.0052$; Fig. 2 ).

Few whakatauki were dated to pre-1350 or post- 1800 . Nonetheless, whakatauki from the early settlement period are shorter (mean length 6.75 words) than whakatauki from the subsequent phase of rapid settlement expansion (AD 1500-1650, mean length 9.13 words; $\mathrm{t}_{304}=-5.10, P<$ $0.001)$. No increase in word length was seen when we compared period 4 (1650-1800, prior to European arrival) and period 5 (1800-, after European arrival) (mean lengths 9.56 and 10.4 words for periods 4 and 5 respectively, $\mathrm{t}_{58}=-0.859$, $P=0.39$ ). In addition, qualitative examination of early whakatauk $\bar{\imath}$ show they are dominated by implicit meanings indicative of closely related family groupings in contrast to whakatauki from later periods in which larger tribal groupings, alliances, and warfare prevail. For example, the brief phrase 'ai pî̀' references overpopulation as a recurring rationale for Polynesian voyaging through the Pacific (Table 1).

Moa form an archetypal group that are strongly overrepresented in whakatauki as in the archaeological record (Figs. 2 and 3). Whakatauki about moa comprise $4.6 \%$ of all faunal whakatauki, and $9.8 \%$ of all whakatauki that specifically mention birds. In striking contrast, other large extinct megafauna, such as the endemic geese and adzebills with adult weights $>15 \mathrm{~kg}$, are not represented in the whakatauki. Indeed, their original Māori names are largely lost (Fig. 4). Māori names for species that became extinct prior to European arrival are now unknown, with the exception of words for moa and pouākai. This loss contrasts with the retention of names for avifauna that became extinct after European arrival. Only one other extinct bird with remarkable body size is mentioned - the Haast's Eagle (Aquila moorei), a giant raptor with a $3 \mathrm{~m}$ wingspan called pouakai or hokioi by Māori. This eagle is the only known apex predator of moa other than humans (Anderson 1989) and quickly followed the moa into extinction.

Qualitative analysis of the dataset indicates that the nature and frequency of moa whakatauki are disproportionally 
Fig. 3 Whakatauki records in relation to time. a Whakatauki that refer to all fauna occur most frequently between $\mathrm{AD} 1500$ 1650. b The abundance and likely importance of moa whakatauki varies through time, as shown by their relative proportion to all faunal whakatauki during each time period. $\mathbf{c}$ The Polynesian founder population c. AD 1280 is generally estimated as $<400$ in size (Whyte et al. 2005), and population expansion was slow in comparison to rapid European settlement in the nineteenth century (Holdaway et al. 2014)
A All Records

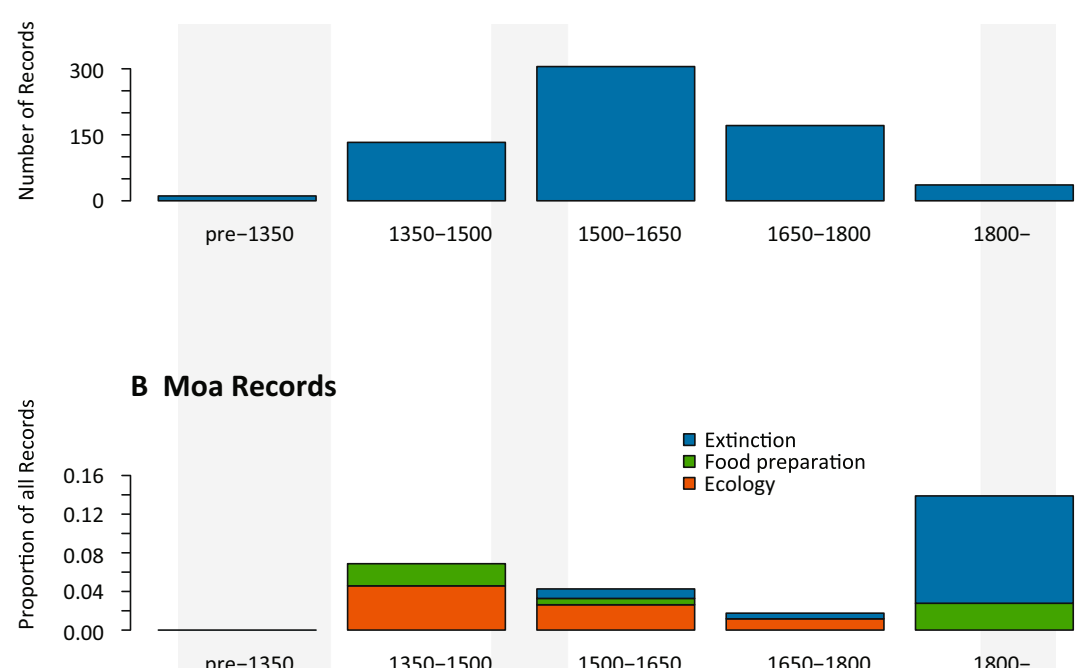

$1800-$ skewed toward two time periods (1350-1500, and post-1800) (Fig. 3). Three main themes emerge from the moa whakatankit: ecological information, food preparation, and concerns about extinction (Fig. 3, Table 1). Ecological observations are especially evident during the early settlement period. The two peaks of whakatauki about moa reflect i) moa ecology and

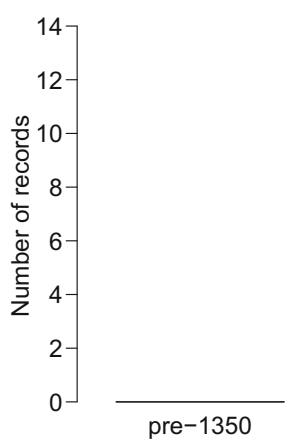

\section{Avian extinctions}
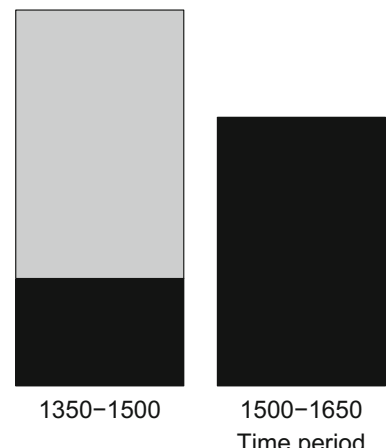

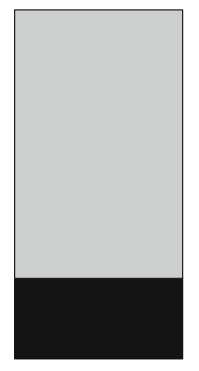

$1800-$

Fig. 4 Most avian extinctions on mainland New Zealand occurred either prior to AD 1500 (within 150 years of Māori arrival), or after European arrival post- $1800 \mathrm{AD}$. 'Moa' is treated here as a name for all nine species of moa, reflecting its indigenous usage; if this group of nine species is treated as one taxonomic unit, the loss of names would be commensurately higher

for species in the 1350-1500 time period. See Table S2 for estimated extinction dates. Key avian extinction periods occurred shortly after Māori and European settlement periods. Grey represents names birds for which the Māori name is no longer known, and black represents bird species or groups for which the Māori name has been retained 
their likely functional extinction around AD 1400-1450, and ii) archetypal links to ideas of extinction for Māori themselves (Table 1) during the social upheaval that followed European colonisation in the early to mid-nineteenth century. Almost all moa whakatauki post-1800 link moa disappearance to impending Māori extinction. In general, the whakatauki dataset demonstrates a trend from simple observation in the early settlement period to awareness of causal agency in later periods (AD 1500-1800; Fig. 5), as expected for the development of traditional knowledge, resource management practices, and conservation 'rules' (Berkes 2008).

\section{Discussion}

The strong relationship between bird size, frequency in the oral record, and frequency in recorded material from archaeological sites indicates that despite the limitations of each of these datasets Māori both targeted and talked about animal species (in this case, birds) that were important food resources. Species that hold strong cultural significance, such as the white heron (Ardea modesta), are also well represented in the whakatauki. While it is difficult to fully test our hypothesis because, for example, small bones are less likely to be found in archaeological deposits, the relationship shown here is clear for all larger bird species.

The frequency of references to moa in the whakatauki provides a powerful contrast to that of other large bird species that became extinct before European arrival. Some large species, such as adzebills, may have had restricted ranges, and therefore might be expected to appear less. Nonetheless, the general absence of references to extinct birds in whakatauki emphasises the language loss that frequently accompanies biodiversity extinction (Maffi 2005).

Given the likely speed with which moa became extinct $(<150$ years) (Perry et al. 2014) it is unsurprising that whakatauki on moa food preparation and on extinction appear to be contemporaneous in the oral record. Diverse and emotive language emphasises the 'loss' and 'death' of moa, suggesting that the extinction of moa was widely noted and discussed. A later set of moa whakatauki appears after European arrival in the nineteenth century and almost uniformly employs the loss of moa as a metaphor for the feared extinction of Māori. This re-mapping of whakatauki concerning the fifteenth century loss of moa to a much later nineteenth century social crisis - the imminent and very real threat of Māori biological and cultural extinction - powerfully emphasizes the impact of moa on the cultural psyche of Māori. The frequency and content of these later whakatauki support the view that Māori were not only aware of the dismal end met by moa, but also that moa extinction came to serve as an archetypal exemplar for extinction more generally.

Whakatauki word lengths in the early period support the predictions of esoteric and exoteric language theory (Wray and Grace 2007), which expected linguistic forms and structures to change with communication context. Early whakatauki indeed carry strongly embedded meanings that reflect close family groupings in contrast to whakatauki from later periods, with larger tribal groupings, which have greater transparency of meaning. That is, interactions with strangers, language contact, and stratification of society all influence language evolution and the way that ecological material is presented. These findings align with the results of the dating methodology, providing confidence in the temporal assignment of language cues and structures identified for each period.

Tracking changes in resource management practices proved challenging using whakatauki. Qualitative analysis reveals a nuanced understanding of ecological relationships in faunal whakataukī from later time periods, for example noting seasonal linkages between species (Table S3, Supplementary Materials). This is consistent with the finding that terms associated with complex social relationships and structures, such as chieftainship and territoriality, increase in frequency
Fig. 5 Whakatauki shift from a predominance of observations early on, towards a rise in causal sayings from 1500 to 1800 , before a further small rise in associative observations after 1800

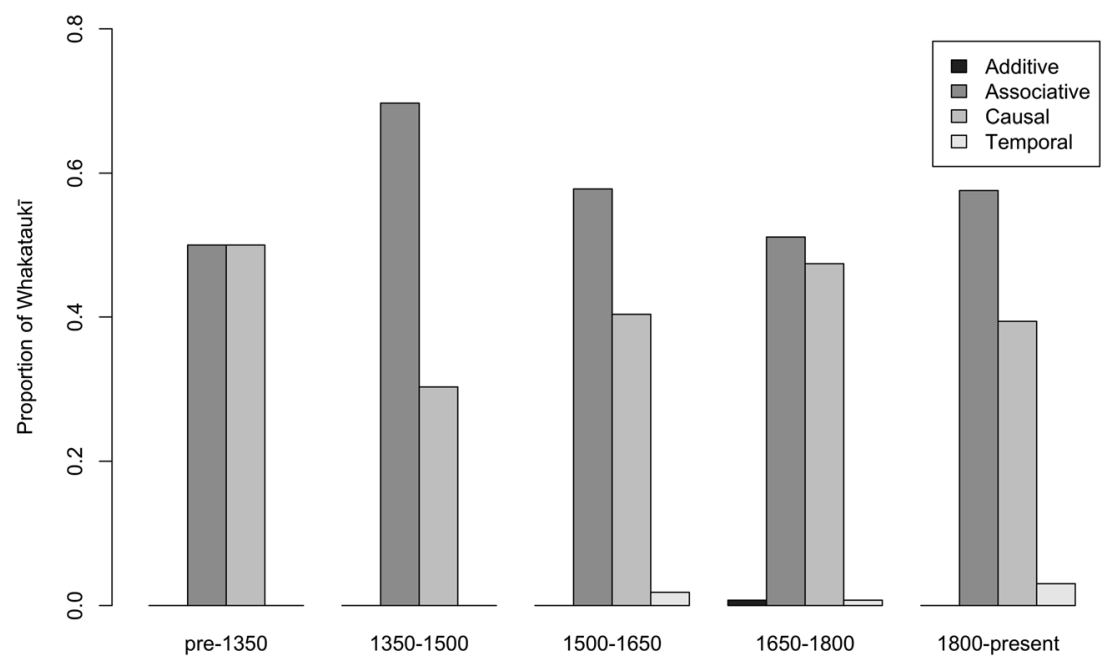


through time (Wehi et al. 2013). Nevertheless, the progression from ecological observations to adaptive management is not clearly reflected in this dataset. One possibility is that the nuances of adaptive management practices are too complex for the brief format of whakatauki (median 8 words, range 236 words, Tables 1 and S3). Notably, specific management practices are not explicitly discussed in any of the faunal whakatauki even though environmental stewardship was widely noted during the nineteenth century by early European writers (Best 1904; Kawharu 2000; Kitson and Moller 2008). For instance, harvests of sooty shearwater $(t \bar{t} t \bar{l})$ have operated continuously for several centuries (Hawke et al. 2003) with defined sustainability practices passed down inter-generationally (Kitson and Moller 2008) and the management of harvests falling largely under the responsibility of chiefs (Best 1904; Kawharu 2000). Our focus on faunal whakatauki may have excluded whakatauki that mention ecosystem-wide management. Ecological management events and environmental frameworks may also be more conspicuous in other forms of oral culture, such as storytelling (Bowman et al. 2015). Alternatively, observation may not necessarily have led to immediate or visible action, perhaps as reflected in the unexpected absence of most large extinct birds in the whakatauki.

Oral tradition, such as these whakatauki passed down by Māori, provide our only real glimpses into the ecological relationships and concerns of early settler populations, and provide early human context to an otherwise relatively dry scientific record of extinction events. The whakatauk $\bar{\imath}$ emphasise that indigenous peoples are not simply passive actors against an environmental backdrop but rather interact with the environment in myriad ways that affect not only the species assemblages present but also the development of cultural values, ideas, and practices. As such, these whakatauki provide evidence of the links between cultural and biological diversity (Maffi 2005). Similar linguistic analysis of other indigenous oral traditions globally could illuminate the development of socioecological world views and conservation learning in other cultures, at least where extinction events are relatively recent. They provide our closest available proxy to the thoughts and responses of the human communities that lived through the big megafaunal extinctions, which occurred very early in human history on the continents.

\footnotetext{
Acknowledgements Trevor Worthy (Flinders University) provided additional information on bird species from archaeological sites throughout New Zealand. We thank Kevin Laland (University of St Andrews) for stimulating discussion, Alan Tennyson (Te Papa National Museum, New Zealand) for advice on extinct bird abundance in prehistoric New Zealand, and Pou Temara (University of Waikato) for assisting with tests of linguistic and historical cues. David Barrell, Emma Brooks, Andreea Calude, Paul Scofield and Dan Tompkins provided constructive comments on an earlier draft of the manuscript. David Wheadon improved the illustrations in Figs. 2 and 3.
}

\section{Compliance with Ethical Standards}

The research was funded by the Royal Society of New Zealand from Marsden funding to H.W and P.M.W. (12-UOW-093) and Rutherford Discovery Fellowships to M.P.C. (RDF-10-MAU-001) and P.M.W. (RDF-14-LCR-001).

Conflict of Interest The authors declare they have no conflict of interest.

Statement of Authorship PMW conceived of the study, and PMW, MPC and HW designed the study. PMW collected data on whakatauk $\bar{\imath}$ and extinct and living species, MPC carried out statistical analyses, TR carried out dating of whakatauki and modern texts and developed methods for language dating, and HW collected data on whakatauki and classified language structure. PMW wrote the first draft of the manuscript. All authors participated in data interpretation and contributed substantially to manuscript development and revisions.

Open Access This article is distributed under the terms of the Creative Commons Attribution 4.0 International License (http:// creativecommons.org/licenses/by/4.0/), which permits unrestricted use, distribution, and reproduction in any medium, provided you give appropriate credit to the original author(s) and the source, provide a link to the Creative Commons license, and indicate if changes were made.

\section{References}

Allentoft, M. E., Heller, R., Oskam, C. L., Lorenzen, E. D., Hale, M. L., Gilbert, M. T. P., Jacomb, C., Holdaway, R. N., and Bunce, M. (2014). Extinct New Zealand Megafauna Were Not in Decline Before Human Colonization. Proceedings of the National Academy of Sciences 111(13): 4922-4927. https://doi.org/10. 1073/pnas.1314972111.

Anderson, A. S. (1989). Prodigious Birds - Moas and Moa-Hunting in Prehistoric New Zealand, Cambridge University Press, Cambridge.

Barbrook, A. C., Howe, C. J., Blake, N., and Robinson, P. (1998). The Phylogeny of the Canterbury Tales. Nature 394(6696): 839-839. https://doi.org/10.1038/29667.

Berkes, F. (2008). Sacred Ecology, Routledge, New York.

Best, E. (1904). Notes on the Custom of Rahui. Its Application and Manipulation, as Also its Supposed Powers, its Rites, Invocations and Superstitions. The Journal of the Polynesian Society 13(2): 8388.

Bowman, D. M. J. S., Gibson, J., and Kondo, T. (2015). Outback Palms: Aboriginal Myth Meets DNA Analysis. Nature 520(7545): 33-33. https://doi.org/10.1038/520033a).

Bromham, L., Lanfear, R., Cassey, P., Gibb, G., and Cardillo, M. (2012). Reconstructing Past Species Assemblages Reveals the Changing Patterns and Drivers of Extinction Through Time. Proceedings of the Royal Society B: Biological Sciences 279(1744): 4024-4032. https://doi.org/10.1098/rspb.2012.1437.

Carlquist, S. J. (1974). Island Biology, Columbia University Press, New York.

Cassey, P. (2001). Determining Variation in the Success of New Zealand Land Birds. Global Ecology and Biogeography 10(2): 161-172. https://doi.org/10.1046/j.1466-822x.2001.00224.x.

Chipere, N. (2000). Processing embedding in humans and connectionist models [Doctor of Philosophy (PhD)]. Cambridge, England, University of Cambridge.

Crombie, W. (1985a). Discourse and Language Learning: A Relational Approach to Syllabus Design, Oxford University Press, Oxford. 
Crombie, W. (1985b). Process and Relational Discourse and Language Learning, Oxford University Press, Oxford.

Crombie, W. (1987). Free Verse and Prose Style, Croom Helm, London. da Silva, S. G., Tehrani, J. J. (2016). Comparative Phylogenetic Analyses Uncover the Ancient Roots of Indo-European Folktales. Royal Society Open Science 3(1). https://doi.org/10.1098/rsos.150645.

Davidson, J. M. (1984). The Prehistory of New Zealand, Longman Paul, Auckland.

Duncan, R. P., Blackburn, T. M., and Worthy, T. H. (2002). Prehistoric Bird Extinctions and Human Hunting. Proceedings of the Royal Society B 269: 517-521. https://doi.org/10.1098/rspb.2001.1918.

Dunning, J. B. (2007). CRC Handbook of Avian Body Masses, CRC Press, Hoboken.

Eagleton, C., and Spencer, M. (2006). Copying and Conflation in Geoffrey Chaucer's Treatise on the Astrolabe: A Stemmatic Analysis Using Phylogenetic Software. Studies in History and Philosophy of Science Part A 37(2): 237-268. https://doi.org/10. 1016/j.shpsa.2005.08.020.

Hawke, D., Newman, J., Moller, H., and Wixon, J. (2003). A Possible Early Muttonbirder's Fire on Poutama, a Rakiura Titi Island, New Zealand. Journal of the Royal Society of New Zealand 33(2): 497507.

Holdaway, R. N. (1989). New Zealand's Pre-human Avifauna and its Vulnerability. New Zealand Journal of Ecology 12(Suppl): 11-25.

Holdaway, R. N., and Jacomb, C. (2000). Rapid Extinction of the Moas (Aves: Dinornithiformes): Model, Test, and Implications. Science 287: 2250-2254. https://doi.org/10.1126/science.287.5461.2250.

Holdaway, R. N., Allentoft, M. E., Jacomb, C., Oskam, C. L., Beavan, N. R., and Bunce, M. (2014). An Extremely Low-Density Human Population Exterminated New Zealand Moa. Nature Communications 5(5436): 1-8. https://doi.org/10.1038/ ncomms6436).

Howe, C. J., and Windram, H. F. (2011). Phylomemetics - Evolutionary Analysis Beyond the Gene. PLoS Biol 9(5): e1001069. https://doi. org/10.1371/journal.pbio.1001069.

Kawharu, M. (2000). Kaitiakitanga: A Maori Anthropological Perspective of the Maori Socio-Environmental Ethic of Resource Management. The Journal of the Polynesian Society 109(4): 349370.

Keegan, P. J., Watson, C. I., Maclagan, M., and King, J. M. (2014). Sound change in Māori and the formation of the MAONZE project. In Onysko, A., Degani, M., and King, J. M. (eds.), He Hiringa, He Pūmanawa: Studies on the Māori Language, Huia, Wellington, pp. $33-54$.

Kitson, J. C., and Moller, H. (2008). Looking After Your Ground: Resource Management Practice by Rakiura Maori Titi Harvesters. Papers and Proceedings of the Royal Society of Tasmania 142(1): $161-176$.

Maffi, L. (2005). Linguistic, Cultural, and Biological Diversity. Annual Review of Anthropology 34: 599-617. https://doi.org/10.1146/ annurev.anthro.34.081804.120437.

Mead, H. M. (1984). Te Māori - Māori Art from New Zealand Collections, Heinemann, Auckland.

Mead, S. M., and Grove, N. (2001). Ngā Pēpeha a Ngā Tīpuna: The Sayings of the Ancestors, Victoria University Press, Wellington.
Perry, G. L. W., Wheeler, A. B., Wood, J. R., and Wilmshurst, J. M. (2014). A High-Precision Chronology for the Rapid Extinction of New Zealand Moa (Aves, Dinornithiformes). Quaternary Science Reviews 105: 126-135. https://doi.org/10.1016/j.quascirev.2014. 09.025 .

Prebble, M., and Wilmshurst, J. M. (2009). Detecting the Initial Impact of Humans and Introduced Species on Island Environments in Remote Oceania Using Palaeoecology. Biological Invasions 11(7): 1529 1556. https://doi.org/10.1007/s10530-008-9405-0.

R Development Core Team (2010). R: A Language and Environment for Statistical Computing, R Foundation for Statistical Computing, Vienna https://www.r-project.org/.

Roa, T. (2016) An exploration of the role of semantic relations in the theory and practice of translation (with special reference to English/Māori and Māori/English translation) [Doctor of Philosophy (PhD)]. Hamilton, New Zealand, University of Waikato.

Spencer, M., Davidson, E. A., Barbrook, A. C., and Howe, C. J. (2004). Phylogenetics of Artificial Manuscripts. Journal of Theoretical Biology 227(4): 503-511. https://doi.org/10.1016/j.jtbi.2003.11. 022.

Tennyson, A. (2006). Extinct Birds of New Zealand, Te Papa Press, Wellington.

Wehi, P. M. (2009). Indigenous Ancestral Sayings Contribute to Modern Conservation Partnerships: Examples Using Phormium tenax. Ecological Applications 19(1): 267-275. https://doi.org/10.1890/ 07-1693.1.

Wehi, P. M., Cox, M., Roa, T., and Whaanga, H. (2013). Marine Resources in Oral Tradition: He Kai Moana, He Kai Mā Te Hinengaro. Journal of Marine and Island Cultures 2: 59-68.

Whaanga, J. P. (2006). Case roles/ relations and discourse relations: A Māori language-based perspective [Doctor of Philosophy (PhD)]. Hamilton, New Zealand, University of Waikato.

Whyte, A. L. H., Marshall, S. J., and Chambers, G. K. (2005). Human Evolution in Polynesia. Human Biology 77(2): 157-177.

Wilmshurst, J. M., Anderson, A. J., Higham, T. F. G., and Worthy, T. H. (2008). Dating the Late Prehistoric Dispersal of Polynesians to New Zealand Using the Commensal Pacific Rat. Proceedings of the National Academy of Sciences of the United States of America 105(22): 7676-7680. https://doi.org/10.1073/pnas.0801507105.

Wood, J. R. (2013). Extinction - New Zealand, 500 years ago. In MacLeod, N., Archibald, J. D., and Levin, P. (eds.), Grzimek's Animal Life Encyclopedia, Chicago, Booklist Publications, pp. 595-604.

Worthy, T. H. (1997). The Identification of Fossil Eudyptes and Megadyptes Bones at Marfells Beach, Marlborough, South Island. New Zealand Natural Sciences 23: 71-85.

Worthy, T. H. (1999). What's on the Menu? New Zealand Journal of Archaeology 199: 125-160.

Worthy, T. H., and Holdaway, R. N. (2002). The Lost World of the Moa: Prehistoric Life of New Zealand, Canterbury University Press, Christchurch.

Wray, A., and Grace, G. W. (2007). The Consequences of Talking to Strangers: Evolutionary Corollaries of Socio-cultural Influences on Linguistic Form. Lingua 117(3): 543-578. https://doi.org/10.1016/j. lingua.2005.05.005. 